Journal of Universal Language 4

Month 2003, 75-89

\title{
Marketing an International Auxiliary Language: Challenges to a New Artificial Language
}

\author{
Neil Olsen
}

Salt Lake City, Utah

\begin{abstract}
This paper examines international auxiliary languages from the point of view that they are products competing in the world linguistic market place. Several factors have contributed to the proliferation of artificial or constructed languages in recent decades. The globalization of social, economic, and intellectual information through the World Wide Web (internet) has made access to the tremendous theoretical and practical progress and educational advances in the field of linguistics, language learning, and language planning. In a world where designer and hobby languages abound, how can an international auxiliary language attract a clientele and achieve the goal of facilitating international communication? The "experiences" of Volapük, Esperanto, Loglan/Lojban, and Klingon are examined as case studies.
\end{abstract}

Keywords: auxiliary language, Volapük, Esperanto, Loglan/Lojban, Klingon 
76 Marketing an International Auxiliary Language

\section{Introduction}

"There may come a time when we have only two languages to learn - our mother tongue and the universal language - and live in a unified global nation without any linguistic discriminations or national conflicts." (Choo 2001: 8)

As optimistic as Choo's statement is, the question remains just what is "the" universal language that one should learn? As with natural languages (English, Spanish, French, Russian, Hindi, Chinese, etc.), there are choices of universal languages competing for speakers (Esperanto, Interlingua ${ }^{1}$, Unish, etc.).

But what type of international language do we need? Margaret Mead and Rudolf Modley set a very high (perhaps unrealistic) standard for the level of this language:

We need a language that can be spoken to very young children; a language that be spoken by a woman giving birth in a foreign hospital or by someone having an emergency operation in a strange country; a language in which a psychiatrist can speak to a disoriented foreign sailor; a language through which a professor can find out what is troubling a brilliant foreign student who is doing badly. We need, indeed, a language that runs the gamut of human experience ... (Mead \& Modley 1968: 59)

An essential question to ask is what utility will the language serve? What level of functionality does the speaker require or desire in such a language? Is it going to be used for basic communication at airports, train stations, hotels, ordering a meal, asking directions

\footnotetext{
${ }^{1}$ There are two languages called interlingua: One was designed by the International Auxiliary Language Association (IALA) and is known as Interlingua de IALA. The other, created by Guise Peano, was originally called Latino sine Flexione, is now known as Interlingua de Peano.
} 
in foreign country, or seeing a doctor? It is going to be used in important business transactions or communicate with academic or professional colleagues at a conference? Or does one want to read a novel or write poetry in that language?

How hard is this language to learn? What resources are there? Can I go to the library and check out a book on this language? Does Readers' Digest, National Geographic, Newsweek, or Scientific American publish issues in this language? If I have access to the World Wide Web, what is available there for me to practice my learning skills? Do I have to learn a strange alphabet? If I live where there is limited access to electronic resources, can I use a typewriter to write this language?

Elgin (1999), the linguist who created Láadan, a woman's language, observes that "A conlang [constructed language] is a language put together with the intention that it should have enough grammar and vocabulary to make it possible for someone to use it to communicate, just as they would use an existing natural language." Most people who create these languages don't ask--much less answer--these questions prior to creating their language, whatever its intended purpose.

\section{International Auxiliary Languages: State of the Art}

International auxiliary languages (IALs) are part of a family tree of artificial or constructed languages. It is generally agreed that artificial or constructed languages (conlangs) fall into three broad categories. The first category encompasses auxiliary languages (auxlangs) which are more utopian in nature and intended to foster and facilitate international communication. Often these are called planned 
languages. ${ }^{2}$ Examples are Volapük, Esperanto, Interlingua, and Unish. The second category includes logical languages (loglangs) created as experiments in logic or philosophical issues, such as Loglan and its successor, Lojban. The third category delineates fictional or artistic languages (artlangs) created for aesthetic pleasure. Languages falling into this category are Tolkien's Quenya, Okrand's Klingon, Elgin's Láadan, and Orwell's Newspeak.

International auxiliary languages exhibit three essential criteria. First, it must be ethnically and political neutral. Second, it must be easy to learn so that anyone can learn it without difficulty. Third, it must be sufficiently functional as a living human language (Lee 2001: 52).

The first criterion is the most difficult to achieve. All natural languages are almost without exception associated with an ethnic, political, or religious group. Diplomatic or religious hegemony has conferred prestige status on languages throughout history from Sumerian to English. A basic dichotomy of constructed languages is based on a priori languages, which have no connection with previously existing natural languages and a posteriori languages, which draw upon existing languages for vocabulary, etc. A priori languages would seem to be better candidates for this criterion.

The second criterion is subjective and relative. Speakers of Spanish, French, and Italian can learn each other's languages with little difficulty, since they share a common ancestry and have similar syntactic characteristics. The same could be said for Germanic, Slavic, Turkic, and Arabic languages. For example, Navajo, a Native American language, is considered by most English speakers to be quite difficult to learn: one has to master a phonological system with sounds that do not exist in English, a completely new lexicon, and a very different syntactic structure. Only the Roman-based orthography is somewhat familiar, despite the pitch accent and nasalization

\footnotetext{
${ }^{2}$ Sometimes the term is restricted to natural languages, such as Bahasa Indonesian.
} 
diacritics. Conversely, most foreign students of English find that language to be difficult, irrespective of their native language.

The third criterion is also subjective and relative. Studies have been conducted on the phonology, morphology, and syntax of hundreds of natural languages and functionality. Consonant rich languages like Georgian and Tlingit seem to function as well as languages at the other end of the spectrum like Hawaiian.

\section{Case Studies: Volapük, Esperanto, Loglan/Lojban, and Klingon}

There is an extensive literature available on most of the languages selected as case studies, particularly Esperanto and Klingon. Therefore, this section will only focus on details germane to this paper. As Andrew Large observes (2002)

The Web has become yet another means for supporters of constructed languages to organize themselves, communicate between themselves and inform the world about themselves. It is an effective way to find [out] about these languages, and a substantial amount of reference material relating to the languages can found on the Web. (Large 2002: 92)

\subsection{Volapük}

The first modern artificial language to achieve any degree of popularity was Volapük. Johann Schleyer, a Catholic priest in Baden, Germany, responding to parishioner complaints about American postal officials not being able to read German script on envelopes, began to think about the concept of an universal alphabet. During this process, he claimed divine intervention in the creation of his international language. After Schleyer published his work in 1880, 
Volapük societies appeared throughout Europe, the Americas, and in Asia, reportedly with over a hundred thousand adherents. "The international language, it seemed in that more innocent age, was an idea whose time had come" (Harlow 2001). Several Volapük world congresses were held (in 1884, 1887, and 1889), and a Volapük Academy was established. However, the fad was not to last; speakers of the language found the complex morphology, myriad verb forms, and lexicon-phonology interface difficult to use. A reform movement surfaced with proposals to simplify the grammar and streamline the lexicon. Even though reformists were elected to the Academy, Schleyer refused to acknowledge their authority, claiming inviolable control over the language. Subsequently, the movement splintered and Volapük's popularity drastically waned by 1900 . This schism spawned at least ten "daughter" languages derived from Volapük. "Languages seem destined to split up into dialects; ironically enough, artificial languages aiming for universality are themselves also victims of this conflict." (Yaguello 1991: 120-121, 191). However, the Volapük movement laid crucial social and linguistic foundations that facilitated the development of Esperanto. ${ }^{3}$

\subsection{Esperanto}

Esperanto is the most widely spoken and best known of the constructed languages. It was developed by, L. Zamenhof, a Polish oculist, who was born and lived in polyglot Bialystok, Poland, then part of the Russian Empire. After trying to learn Volapük, and finding it too difficult, he devised his own language during the period from 1872 to 1885 . In 1887, he published the first textbook for Russian speakers; an English translation appeared in 1889. By 1891, textbooks, booklets, and dictionaries had been issued in twelve lan-

\footnotetext{
${ }^{3}$ Volapük is reportedly making a comeback on the Web; additionally, Lincom Europa has recently published a survey of several "mixed" artificial languages including Volapük (Libert 2002).
} 
guages. Esperanto has a voluminous literature, including radio broadcasts, movies, and other media. ${ }^{4}$

Esperanto is considered an a posteriori language. If one accepts the assumption that constructed languages are pidgins, then Esperanto includes the following lexifiers: Latin, French, German, English, Russian, Polish, Greek, and Hebrew. ${ }^{5}$ All of these are IndoEuropean languages, except for Hebrew, which is Semitic.

According to a comprehensive survey by Sidney Culbert, formerly of the University of Washington at Seattle, between 1 and 2 million people claim to speak Esperanto at some level of proficiency. There are 200 to 2,000 native speakers; if this is true, then Esperanto has undergone creolization. Esperanto has also engendered numerous "daughter" languages (see table 2.7.4 in Appendix 2 of Yaguello 1991: 192-193).

\subsection{Loglan/Lojban}

Loglan (a logical language) was originally developed in the 1950s by James Cooke Brown as a empirical tool to test the SapirWhorf hypothesis, in which "the native speaker of any language is fated to see reality, and to think about it, exclusively on the terms and by the rules laid down for him by that language-unless he learns a new one." (Brown 1960: 53) An early version described in Scientific American "was to have a small, easily learned vocabulary derived from the word stock of as many of the major natural languages as proved feasible (though it was not intended to be an auxiliary international language)." (Brown 1960: 55). The grammar is based on predicate calculus and intended to be ambiguity-free. The vocabulary - the lexicon - was designed to be generated by an algorithm based on the eight most widely spoken natural languages (in

\footnotetext{
${ }^{4}$ An excellent resource is <http://www.esperanto.org $>$.

${ }^{5}$ A lexifier is the language from which a pidgin derives most of its vocabulary.
} 
the 1950s): English, Chinese, Hindi, Russian, Spanish, French, Japanese, and German. These eight languages totaled 1.7 billion speakers representing over two thirds of the world's population. These lexifier languages were ranked statistically by the proportion of speakers to the total universe of the eight languages: English, 0.28; Chinese 0.25; Hindi, 0.11; Russian, 0.10; Spanish 0.09; Japanese and French, both 0.06; and German 0.05. Only phonemes common to and occurring in the same order in the Loglan and the source language natural words were considered. It is claimed that these cognates improve the learnability of each word (Brown 1960: 55-58). Information on Loglan is available from The Loglan Institute, Inc., which maintains a web site <http://www.loglan.org> and issues publications (e.g., Brown 1989). ${ }^{6}$

As was the case with Volapük and Esperanto, a group of Loglanists disagreed with some of the policies of the The Loglan Institute. In 1987, they started their own group, The Logical Language Group, and launched Lojban, which is conceptually similar to Loglan, although the vocabulary is different due to legal and copyright issues (Keith 1998). ${ }^{7}$ Other Loglan "daughter" languages include Voksigid and Ceqli.

\subsection{Klingon}

Klingon is a fictional language designed by linguist Marc Okrand in 1985 for the science fiction television series Star Trek, created by Gene Roddenberry. The language was intended to be spoken by the Klingons, an alien warrior race that appeared in the series and subsequent films. Created as a fictional language, it was never meant to be used for human communication. It has a guttural phonology and a difficult syntax employing a very rare word order (ob-

\footnotetext{
${ }^{6}$ Unish employs a similar lexification process, which is discussed in Chung (2001).

${ }^{7}$ The Logical Language Group web site is 〈http://www.lojban.org >.
} 
ject-verb-subject) found only in a few natural languages (e.g., Hixkaryana, a Carib language of N. Brazil) (Comrie 1989: 20, 31). Klingon is a clear case of an a priori language with no lexifier(s).

While creating the Klingon language, Okrand realized its market potential and convinced a publisher of the commercial viability of a dictionary. As of 1995, The Klingon Dictionary (Okrand 1992b) had sold a quarter of a million copies, not including its companion audio cassette tape Conversational Klingon (Okrand 1992a). The Klingon Language Institute (KLI), established in 1992, by Lawrence Schoen, has members worldwide and publishes a quarterly linguistic journal, HolQeD. The KLI maintains a web site with resources on the history, development, spoken, and written aspects of the language. ${ }^{8}$ It also sponsors several projects to translate the Christian Bible and the works of William Shakespeare into Klingon. The book of Jonah and St. Mark's Gospel has been completed; these works were translated directly from the original Hebrew and Greek, not an English version. Hamlet and Much Ado About Nothing have also been published. ${ }^{9}$

If Klingon is clearly not easy to learn, then why is it so popular? There are several reasons.

Klingon's creator linguist Okrand explains:

It's a fun language to speak. You do get to shout and spit and clear your throat out. Being a Klingon is fun because if you're a Klingon you can do things you can't do if you're a boring Federation human. The internet is the thing that's making it work, there's no question about. If there weren't an internet, it wouldn't be growing the way it is. (Oliver 1996)

\footnotetext{
${ }^{8}$ Interestingly, the Klingon Language Institute web site <http://www.kli.org > allows users to access Esperanto and Lojban translations.

${ }^{9}$ Most Klingon products (books, cassettes, and other paraphernalia) are readily available through retail outlets such as Amazon.com and Barnes and Noble booksellers.
} 
Lawrence Schoen, director of the KLI adds:

What does make Klingon different-and truly unique among the loose family of constructed languages-is the population from which it draws its speakers. They come from all walks of life, all levels of education, all socio-economical and political strata. Klingon benefits from the almost universal appeal that defines the Star Trek phenomenon, and the KLI has unabashedly ridden those coattails to promote and spread the language. (Schoen 2002)

Klingon is the only language is which there have been the equivalent of market surveys conducted. Stefan Annernas (1996) compiled data collected from the Web and found that the majority of 604 respondents were Caucasian, American males with at least a university education and employed in a computer-related profession. They had learned about Klingon from television or movies, owned a copy of The Klingon Dictionary, and had studied the language for 1 to 2 years. The majority rated their language skill level as postbeginner. Most used Klingon daily on a listserv or newsgroup.

Following up on Annernas' survey, Judith Hermans found that Klingon is inextricably linked to the Star Trek phenomenon. She created a sociolinguistic profile of the "average Klingon user":

The average Klingon user in my survey is a Caucasian male, about 31.5 years old, living in a city somewhere in the United States. He could be single or married. He speaks English as his first language and has a high education, what [sic] has resulted in a job as an IT [information technology] worker or he is still a student. He has discovered Klingon via Star Trek, which he likes very much. Via books written by Marc Okrand he has started to learn the language. He has studied Klingon for 1 to 4 years now and he uses it less than once a month. When he uses it, he uses it 
to practise his Klingon grammar and to read and write messages from/to other persons. He also talks with other Klingon speaker, usually at meetings. (Hermans 1999: 48)

Hermans notes that Klingon users are a subgroup of Trekkies, who tend to be students or work in the information technology (IT) sector of the economy. These groups have access to the Internet and when they use Klingon, it is done primarily on the Internet (Hermans 1999: 49-52).

\section{Implications for Unish and Other IALs in the World Market Place}

If we are to consider an IAL as a product competing in the world market place, what is the best strategy to pursue? Viewing this from a commercial perspective, the first question would be to ask "what is the market?" What demographics are available for competing products? Has anyone conducted a marketing study?

Examining the case studies presented above, only Klingon language users have been surveyed recently. ${ }^{10}$ The results of these surveys demonstrate that although Klingon enjoys a current popularity that approaches and sometimes exceeds Esperanto, it is a very narrow niche market. It is highly correlated to post-secondary education, access to the Web, and involvement with the Star Trek phenomenon and its novelty appeal.

Section 1 detailed some of the essential questions that need to be asked concerning the potential users of an IAL, what level of use is intended or anticipated, what resources will be available, etc.

\footnotetext{
${ }^{10}$ The more comprehensive Culbert survey referred to previously was conducted several decades ago and was apparently never published although it is extensively quoted (e.g., in the Ethnologue); it is not clear if data concerning artificial languages other than Esperanto were collected.
} 
Will the IAL be a stable product? As we have seen in the case studies, although IALs by their nature are prescriptive, Volapuk, Esperanto, and Loglan all experienced problems of schism. Even artificial languages are vulnerable to fusion. What is important to note is that constructed languages-artificial as they may be-start to function and evolve over time as natural languages do (Yaguello 1991: 121).

Modern trends in language learning principles need to be exploited. Studies on the time invested, the motivation, and peer pressure of learning a language have been documented. What is the value, the payback, the return on investment of the time and effort expended on learning a particular language? Is it more cost effective to learn a language or to pay a translator on an as-needed basis, thus freeing up time to learn something else?

How do you present an IAL that is more attractive that the national language taught in the schools that is reinforced by universal education? How do you fund mass communication media outlets to produce newspapers, magazines, books, comic books, radio and television programs in the target IAL?

Although some hard questions have been presented, and not all of them answered, Edward Sapir offers a cogent thought on an international language:

A standard international language should not only be simple, regular, and logical, but also rich and creative. Richness is a difficult and subjective concept. It would, of course, be hopeless to attempt to crowd into an international language all those local overtones of meaning which are so dear to the heart of the nationalist. But there is a growing fund of common experience and sentiment which will have to be expressed in an international language, and it would be strange if the basic fund of meanings would not grow in richness with the interactions of human beings who make use of the new medium. The supposed inferiority 
of a constructed language to be a national one on this score is, of course, no criticism of the idea of constructed languages. All that it means is that the constructed language has not been in longcontinued use. As a matter of fact, a national language which spreads beyond its own confines very quickly loses much of its original richness of content and is in no better case than a constructed language. (Sapir 1931: 207)

\section{Summary and Conclusions}

Both endangered natural languages and nascent artificial languages, especially IALs, share a commonality with respect to attaining and maintaining a critical mass of speakers. There is an inverse relationship in this commonality. In the case of endangered languages, when the number of declining speakers reaches a crucial point, it triggers a process of documentation, along with decisions whether to preserve and maintain the language (Olsen 2000). On the other hand, IALs struggle to reach and attain that critical mass of adherents/users/speakers that signals the acceptance and subsequent survival of that language. Proponents of potential IALS could learn from the experience of linguists and others working to at least document, if not preserve, endangered languages.

At the far end of the spectrum, one might advocate the "killing of two birds with one stone"; that is an endangered or extinct language be proposed as an international auxiliary language, such as $\mathrm{Bu}$ rushaski, Nez Perce, Rapa Nui (Easter Island), Lardil, or even Egyptian or Sumerian. This would neutralize cultural and political bias and remove accusations of Eurocentrism that are raised with some $a$ posteriori IALs. The learnability factor would be equalized among most speakers, since the majority are language isolates (i.e., not related to extant languages). While this proposal might sound extreme, Sumerian, Egyptian, Hittite, Akkadian, (written) Chinese, Sanskrit, 
Greek, and Latin have all functioned as international languages.

Elgin's challenge to maintaining a constructed language applies equally to Unish and other IALs:

Constructing a language is formally easy, especially with today's computers. Any competent linguist can run up half a dozen in just a few hours or program the computer to spit them out at a fantastic rate. (...) Making the language interesting, which is art rather than science, is much harder. Making it a living language, used by living human beings attached to a living culture, is enormously difficult. It's hard enough to keep natural languages alive, hard enough that we're losing them today by the hundreds; keeping a conlang alive is a quantum leap in difficulty. (Elgin 1999: 1-2)

\section{References}

Annernäs, S. 1996. Klingon Questionnaire. Available at URL <http://home1.swipnet.se/ w-12689/survey.htm>.

Brown, J. 1960. Loglan. Scientific American 202, 53-63.

Brown, J. 1989. Loglan 1: A Logical Language ( $4^{\text {th }}$ edition). Gainesville, FL: The Loglan Institute.

Choo, M. 2001. The Need for "Unish", a Universal Language and the Principles of its Development. Journal of Universal Language 2, 3-14.

Comrie, B. 1989. Language Universals and Linguistic Typology $\left(2^{\text {nd }}\right.$ edition). Chicago, IL: The University of Chicago Press.

Cowan, J. 1997. The Complete Lojban Language ( $1^{\text {st }}$ edition). Fairfax, VG: The Logical Language Group, Inc.

Elgin, S. 1999. "Láadan, the Constructed Language in Native Tongue." Available at URL <http://www.sfwa.org/members/elgin/Laadan.html>.

Hermans, J. 1999. "Klingon and its Users: A Sociolinguistic Profile." M.A. thesis. Tilburg: Tilburg University. Available at URL <http://www. geocities.com/judith_hh/scripdef.htm>.

Keith, A. 1998. Other Constructed Languages. Available at URL 
<http://www.loglan.org/other-conlang-info.html>.

Large, A. 2002. The New Babel: Language Barriers on the World Wide Web. Journal of Universal Language 3, 77-95.

Lee, C. 2001. An Agenda for Action toward a New International Language Order. Journal of Universal Language 2, 51-60.

Mead, M. \& R. Modley. 1968. Communication among All People, Everywhere. Natural History 77.7, 56-63.

Okrand, M. 1992a "Conversational Klingon." Read by M. Dorn, Audiocassette. New York: Simon and Schuster, Audioworks.

Okrand, M. 1992b. The Klingon Dictionary: English/Klingon, Klingon/English. New York: Pocket Books.

Oliver, G. 1996. Vaj TlhIngan Hol Dajathlh 'e' DaneH: So you Want to Speak Klingon. Available at URL <http://www.canoe.ca/Jam BooksFeatures/okrand_marc.html>.

Olsen, N. 2000 The Future of Koho: A Mon-Khmer Language of Viêt Nam. In Ostler, N \& B. Rudes (eds.), Endangered Languages and Literacy: Proceedings of the $4^{\text {th }}$ Foundation for Endangered Languages Conference 43-46. Bath: The Foundation for Endangered Languages.

Sapir, E. 1931. Wanted: A World Language. American Mercury 22.86, 202-209.

Schoen, L. 2002. "No. of Klingon Speakers." E-mail to the Author. 25 June.

Yaguello, M. 1991. Lunatic Lovers of Language: Imaginary Languages and their Inventors. London: The Athlone Press. 